Article

\title{
Verification of the Influence of Loading and Mortar Coating Thickness on Resistance to High Temperatures Due to Fire on Load-Bearing Masonries with Clay Tiles
}

\author{
Rodrigo P. de Souza ${ }^{1}$, Fernanda Pacheco ${ }^{2}$, Gustavo L. Prager ${ }^{2}$, Augusto M. Gil ${ }^{3}$ (i), \\ Roberto Christ ${ }^{2}$, Vinícius Muller de Mello ${ }^{2}$ and Bernardo F. Tutikian 2,4,*(D) \\ 1 PPGEC, UNISINOS, São Leopoldo, RS 93022-750, Brazil; pericorodrigo@gmail.com \\ 2 Civil Engineer Program, PPGEC/Itt Performance, UNISINOS, São Leopoldo, RS 93022-750, Brazil; \\ fernandapache@unisinos.br (F.P.); gprager@unisinos.br (G.L.P.); rchrist@unisinos.br (R.C.); \\ vmullerm@edu.unisinos.br (V.M.d.M) \\ 3 Department of Civil and Environmental Engineering, Michigan State University, East Lansing, MI 48824, \\ USA; masierog@msu.edu \\ 4 Departamento de Civil y Ambiental, Universidad de la Costa, Barranquilla 080020, Colombia \\ * Correspondence: bftutikian@unisinos.br; Tel.: +55-5198-428-3600
}

Received: 30 August 2019; Accepted: 29 October 2019; Published: 7 November 2019

check for updates

\begin{abstract}
Masonry has been widely used as a construction method. However, there is a lack of information on its fire behavior due to the multitude of variables that could influence this method. This paper aimed to identify the influence of loading and mortar coating thickness on the fire behavior of masonry. Hence, six masonries made of clay tiles laid with mortar were evaluated. The mortar coating had a thickness of $25 \mathrm{~mm}$ on the face not exposed to high temperatures, while the fire-exposed face had thicknesses of 0,15 , and $25 \mathrm{~mm}$. For each mortar coating thickness, two specimens were tested, with and without loading of $10 \mathrm{tf} / \mathrm{m}$. The real-scale specimens were subjected to the standard ISO 834 fire curve for four hours, during which the properties of stability, airtightness, and thermal insulation were assessed. Results showed that loaded specimens yielded smaller deformations than unloaded ones. Samples that lacked mortar coating on the fire-exposed face underwent fire resistance decrease of $27.5 \%$, while the ones with $15 \mathrm{~mm}$ decreased by $58.1 \%$, and the ones with $25 \mathrm{~mm}$ decreased by $41.0 \%$. As mortar coating thickness increased, the plane deformations decreased from $40 \mathrm{~mm}$ to $29 \mathrm{~mm}$ and the thermal insulation properties of the walls improved significantly. For specimens with mortar coating thickness of $25 \mathrm{~mm}$, the load application resulted in a reduction of $23.8 \%$ of the thermal insulation, while the unloaded specimen showed a decrease of $43.3 \%$, as well as a modification of its fire-resistance rating.
\end{abstract}

Keywords: structural masonry; mortar coating; fire resistance

\section{Introduction}

When fire strikes a structural masonry building, it endangers the building's physical structure and the life of its occupants [1]. A fire usually develops in four stages: incipient, growth, fully developed, and decay, abiding by a typical temperature-time curve during this process [2]. The thermal action from fire conditions is described by radiation and convection heat transfer mechanisms, whereas the heat from the fire can spread by conduction, convection, and radiation [3]. Several technical standards specify conditions for safe building operations and even include exceptional events such as fires [4]. There are also functional safety requirements concerning fire prevention and extinguishing, ways to 
limit fire spread and prevent damages and even collapse, along with safe user evacuation methods and safe access routes for rescue teams and firefighters $[5,6]$.

Compartment walls and floors are part of these considerations, as they pose as fire-resistant elements that strive to stop fire from spreading to adjacent rooms [7]. According to Al-Hadhrami and Ahmad [8], masonry walls made with clay bricks can be used for horizontal compartmentalization and as firewalls. As per Nguyem and Meftah [9], the fire resistance of masonry walls can be determined either by laboratory tests or by semi-empirical methods that are more conservative. The fire resistance of masonry walls covers three safety levels represented by structural stability, air and smoke tightness, and thermal insulation, according to [10], as well as the main standards related to the fire protection test [11-14]. Gomes-Heraz et al. [15] pointed out that heating with real flames is the most realistic approach to analyze the fire resistance of various materials. Regarding structural stability, it evaluates the preservation of mechanical strength, maintaining the safe distribution of loads to the foundation [16]. Airtightness refers to the capacity of the wall to prevent the passage of flames and hot gases through cracks that may appear [17]. For Ono [18], thermal insulation is the criterion that evaluates if the heat on the fire-exposed surface of the building element poses a risk to the people and the objects occupying rooms that are adjacent to the unexposed face.

As for thermal resistance, clay bricks rely on the specific gravity of their constituting materials. Moreover, masonry with hollow cores hinder heat transfer [4]. According to the Brick Industry Association (BIA) [19], the cavities of clay bricks make heat transfer happen through convection and radiation. The internal temperature distribution profile in fire resistance tests suggests that temperature distribution is not linear because it is influenced by the thickness of the wall and the heating rate $[20,21]$. The concavity of the curve generated by thermal action is higher for thinner walls and it increases along with the heating rate [20]. Considering heat storage and dissipation, the main factors that can influence the thermal inertia of a wall are: the thickness of the wall, specific gravity, specific heat capacity, and the thermal conductivity of the materials. Beall [22] states that thermal inertia contributes to the fire resistance of masonry, as it hinders heat transfer.

When subjected to high temperatures, masonry tends to bend towards the fire. According to Ono [18], stability is more relevant for load-bearing masonry. The degradation of materials exposed to high temperatures, added to differential thermal expansion, may bring the element to collapse depending on the deterioration degree [20]. As per Ayala [23], there are other critical factors that strive to maintain stability such as the heating ratio, exposure time, and moisture conditions. The degradation of materials after exposure to high temperatures, the bending resulting from thermal expansion, the restrictions, the geometry of the wall, and the presence of eccentricities from the strength lost by the fire-exposed face are interconnected [16]. Figure 1 depicts the arching towards the side with higher temperature, which is typical of clay masonry.

A wall that has been subjected to compressive axial stress shall yield second order effects that can be reduced during the initial stages of load application. Vertical loading tends to cause problems after a long period of exposure as the element tends to become laterally unstable due to the steep stresses produced by the moments from lateral displacement [24]. Nevertheless, Nadjaii, O'Gara and Ali [25] managed to perform numerical simulations of a masonry wall to analyze the influence of the eccentricity of load application, the slenderness of the wall, and the type of binding. In terms of loading in fire conditions, non-load bearing masonry presents displacements on both axes around it, with greater deformation at the center of the sample, behaving as if it were fixed on the four corners [3]. As for load-bearing masonry, the displacements are smaller and there is a restraint at the top and the base of the masonry, as depicted in Figure 2. In conclusion, loading has direct effect on the global displacement of masonry. 


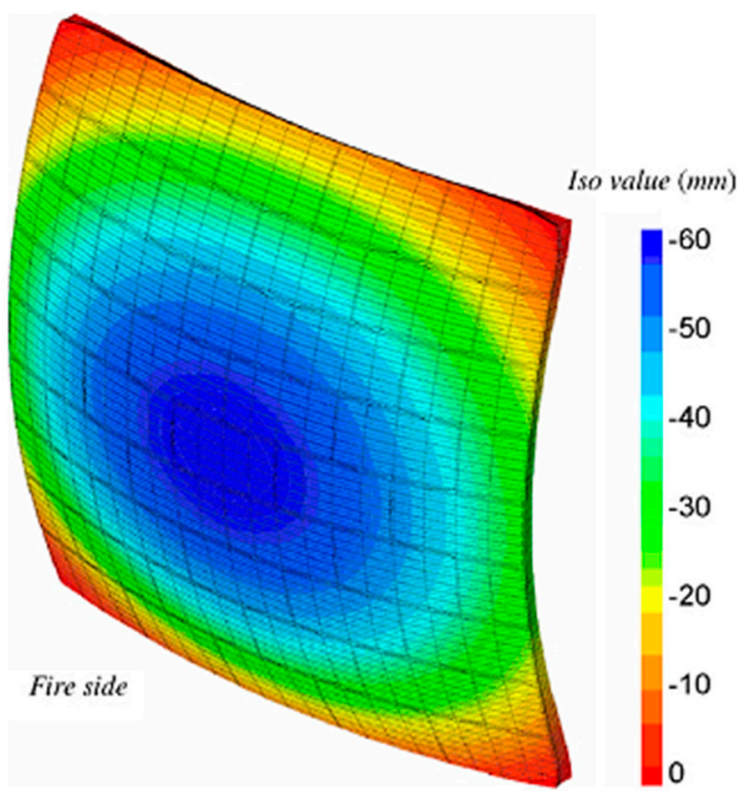

Figure 1. Displacement of the wall nearing the heat source [21].

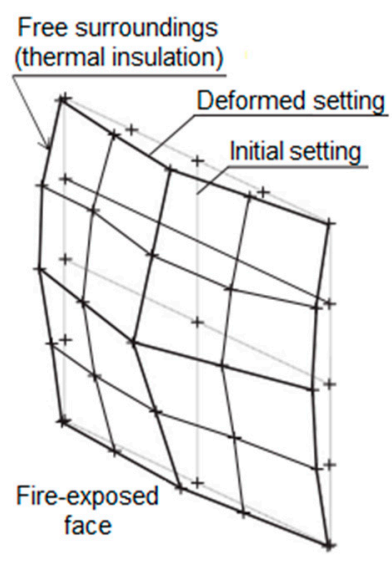

(a)

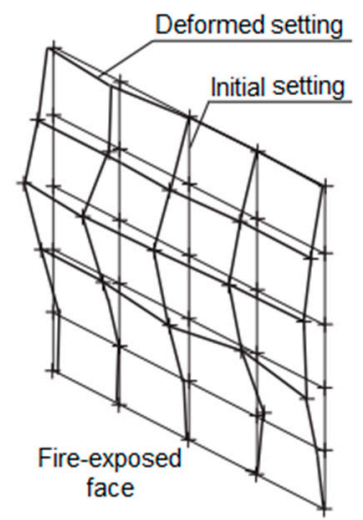

(b)

Figure 2. Deformations endured by fire-exposed masonry (a) non-load bearing wall and (b) load-bearing wall, as per Nguyen and Meftah [9].

Nguyen and Meftah [9] linked the simultaneous occurrence of explosive spalling and vertical loads to the increased bending moment, owing to the eccentricity of the load applied. Spalling creates a zone of brittleness that allows warping and affects the sample as a whole, and local failure is an important factor for the performance of masonries in fire conditions. Load-bearing masonry walls undergo progressive compressive strength loss due to the deterioration of the mortar coating at high temperatures [26-28]. Experimental studies revealed that, upon receiving loads, the walls mitigated the increase of deformations. Silva, Oliveira and Sobrinho [29] observed that applying $30 \mathrm{~mm}$ thick mortar coating to both faces of prisms could increase load-bearing capacity by over $300 \%$. Mortar coating reduces bending in comparison to uncoated samples. Still, there are few studies that provide background on the performance of load-bearing masonries with respect to fire. Therefore, this study aimed to assess the effect of mortar coating and loading on load-bearing walls made of clay tiles subjected to high temperatures. 


\section{Materials and Methods}

The experimental procedure comprised of six fire resistance tests, as shown in Table 1.

Table 1. Sample nomenclature.

\begin{tabular}{cccc}
\hline \multirow{2}{*}{ Samples } & Internal Side & External Side & Loading \\
\cline { 2 - 4 } & Mortar Coating $(\mathbf{m m})$ & Mortar Coating $\mathbf{( m m )}$ & $\mathbf{( t f} / \mathbf{m})$ \\
\hline Wall 1 (W1) & None & 25 & None \\
Wall 2 (W2) & None & 25 & 10 \\
Wall 3 (W3) & 15 & 25 & None \\
Wall 4 (W4) & 15 & 25 & 10 \\
Wall 5 (W5) & 25 & 25 & None \\
Wall 6 (W6) & 25 & 25 & 10 \\
\hline
\end{tabular}

\subsection{Sample Composition}

All walls were made up of clay tiles laid with mortar, with $1 \mathrm{~mm}$ thick vertical and horizontal joints. All samples had their unexposed face coated with $25 \mathrm{~mm}$ thick mortar. On the fire-exposed face, the coating was null for the reference walls, and $15 \mathrm{~mm}$ or $25 \mathrm{~mm}$ for the others, in order to evaluate the influence of mortar on fire resistance. The walls were executed within metal frames with internal span of $3.15 \mathrm{~m} \times 3.00 \mathrm{~m}$ and curing lasted 56 days. The materials used during the investigation were cement type III from ASTM C150 [30], two types of silica sand whose particle-size distributions are presented in Table 2 in accordance with EN 933-1 [31], structural clay tiles with dimensions of $14 \mathrm{~cm}$ $\times 19 \mathrm{~cm} \times 29 \mathrm{~cm}$ (width, length, and height) and properties presented in Table 3, characterized as per ASTM C-652 [32], and traditional mortar for laying and coating. The fresh and hardened state properties of the coating mortar were assessed, with the results being shown in Table 4 .

Table 2. Distribution of fine aggregates-EN 933-1 [31].

\begin{tabular}{|c|c|c|c|c|}
\hline \multirow[t]{2}{*}{ Sieve $(\mathrm{mm})$} & \multicolumn{2}{|c|}{ Roughcast } & \multicolumn{2}{|c|}{ Mortar for Laying and Coating } \\
\hline & Retained (\%) & Cumulative (\%) & Retained (\%) & Cumulative (\%) \\
\hline 4.8 & 4 & 4 & 0 & 0 \\
\hline 2.4 & 6 & 10 & 0 & 0 \\
\hline 1.2 & 11 & 21 & 0 & 0 \\
\hline 0.6 & 13 & 34 & 7 & 7 \\
\hline 0.3 & 36 & 70 & 30 & 37 \\
\hline 0.15 & 28 & 98 & 54 & 91 \\
\hline$<0.15$ & 2 & 100 & 9 & 100 \\
\hline Total & 100 & - & 100 & - \\
\hline Maximum size (mm) & \multicolumn{2}{|c|}{4.8} & \multicolumn{2}{|c|}{1.2} \\
\hline Fineness modulus & \multicolumn{2}{|c|}{2.37} & \multicolumn{2}{|c|}{1.35} \\
\hline Specific gravity $\left(\mathrm{g} / \mathrm{cm}^{3}\right)$ & \multicolumn{2}{|c|}{2.61} & \multicolumn{2}{|c|}{2.63} \\
\hline Loose bulk density $\left(\mathrm{g} / \mathrm{cm}^{3}\right)$ & \multicolumn{2}{|c|}{1.48} & \multicolumn{2}{|c|}{1.55} \\
\hline
\end{tabular}

Table 3. Characterization of clay tiles according to ASTM C-652 [32].

\begin{tabular}{|c|c|c|}
\hline & Tests & Values \\
\hline \multirow{6}{*}{ Physical properties } & Length (mm) & 291 \\
\hline & Width (mm) & 139 \\
\hline & Height $(\mathrm{mm})$ & 191 \\
\hline & Warpage of surfaces (mm) & 0.5 \\
\hline & Chippage $(\mathrm{mm})$ & 0.5 \\
\hline & Total absorption (\%) & 18 \\
\hline Mechanic properties & Compressive strength $(\mathrm{MPa})$ & 8.65 \\
\hline
\end{tabular}


Table 4. Characterization of the mortar for laying and coating.

\begin{tabular}{ccc}
\hline & Characterization Tests & Result \\
\hline \multirow{3}{*}{ Fresh state } & Flow level (mm) C-1437 (ASTM, 2015) & 265 \\
& Air content (\%) C-231 (ASTM, 2017) & 3.5 \\
& Density $\left(\mathrm{kg} / \mathrm{m}^{3}\right)$ C-185 (ASTM, 2015) & 1855.5 \\
\hline \multirow{3}{*}{ Hardened state } & Compressive strength (MPa) C-109 (ASTM, 2016) & 4.7 \\
& Flexural strength $(\mathrm{MPa})$ C-348 (ASTM, 2014) & 1.84 \\
& Density $\left(\mathrm{kg} / \mathrm{m}^{3}\right)$ C-1754 (ASTM, 2012) & 1709 \\
& Capillary water absorption $\left(\mathrm{g} / \mathrm{dm}^{2} \cdot \mathrm{min}^{\frac{1}{2}}\right.$ ) C 1403 (ASTM, 2015) & 5.8 \\
& Void ratio $(\%)$ C-1754 (ASTM, 2012) & 28.76 \\
\hline
\end{tabular}

\subsection{Sample Instrumentation}

\subsubsection{Measurement of Displacements}

The displacements were measured with a Leica TS15 Robotic Total Station with an angular accuracy of $\pm 3^{\prime \prime}$ and linear accuracy of $\pm\left(1 \mathrm{~mm}+1.5 \mathrm{~mm} \mathrm{~km}^{-1}\right)$, placed on a metal tripod $6 \mathrm{~m}$ away from the unexposed face. After these measurements, the Cloud Compare software was used to process the 3D point cloud. According to Georgantas, Bredif, and Pierrot-Desseilligny [33], Cloud Compare offers several alternatives to measure the distance between two dot clouds, two meshes, or even between a cloud and a mesh. This study measured two specific clouds before and during the test. The software program then generated a local model for a reference point cloud and granted total and local accuracy over the distance calculated between the two-point clouds to measure the displacements.

\subsubsection{Temperature Measurement}

Temperature evolution was monitored continuously during the test, considering that two thermocouples were installed inside the furnace to measure internal temperature. During the test, the temperature of the exposed face is the arithmetic mean of the temperatures measured by five thermocouples symmetrically arranged within the oven, one at the center of the sample and the others at the center of each quadrant, minding the same positioning on the unexposed face. Besides the internal and external thermocouples, 10 thermocouples were added along the cutting of the clay tiles and the coating, as depicted in Figure 3. The thermocouples were inserted in holes that had been drilled on the wall. It was not necessary to repair the wall because the hole and the thermocouple had similar dimensions, and it was assumed that adding other materials to these spots would alter the measurements. These data made it possible to define the temperature profile, assessing the influence of coating thickness and thermal inertia of the masonry. The thermocouples were installed on the 55th day of curing along the thickness of the wall, in its inner core and the center of two tiles, according to the following distances:

- First position $(\mathrm{d}=0 \mathrm{~cm})$, face of the tile exposed to fire regardless of the coating;

- Second position $(\mathrm{d}=3 \mathrm{~cm}), 3 \mathrm{~cm}$ away from the fire-exposed face plus coating thickness;

- Third position $(\mathrm{d}=7 \mathrm{~cm})$, axis of the tile;

- Fourth position $(\mathrm{d}=11 \mathrm{~cm}), 4 \mathrm{~cm}$ away from the axis of the tile;

- Fifth position $(\mathrm{d}=14 \mathrm{~cm}), 7 \mathrm{~cm}$ away from the axis of the tile, on the external face of the tile.

The instrumentation relied on the use of type $\mathrm{K}$ thermocouples with $6 \mathrm{~mm}$ of diameter to measure the temperature within the furnace and on the fire-exposed face. The thermocouples along the thickness of the wall and on the unexposed surface were type $\mathrm{K}$ with $1.5 \mathrm{~mm}$ of diameter. The thermocouples on the external face were type $\mathrm{T}$ and were attached to copper disks with $12 \mathrm{~mm}$ of diameter and $0.5 \mathrm{~mm}$ of thickness. The procedure was complemented with a FLIR thermographic camera model A320 with a resolution of $320 \times 240$ pixels, sensitive to wavelengths of 7.5 and $13 \mu \mathrm{m}$, with a temperature gradient of $0{ }^{\circ} \mathrm{C}$ to $350{ }^{\circ} \mathrm{C}$ and a thermal resolution of $\pm 2{ }^{\circ} \mathrm{C}$, in order to analyze the temperature distribution 
and make it easier to identify airtightness. Moreover, the results presented in item 3 were obtained by the interpolation of temperature measurement spots that were counted with thermocouples.
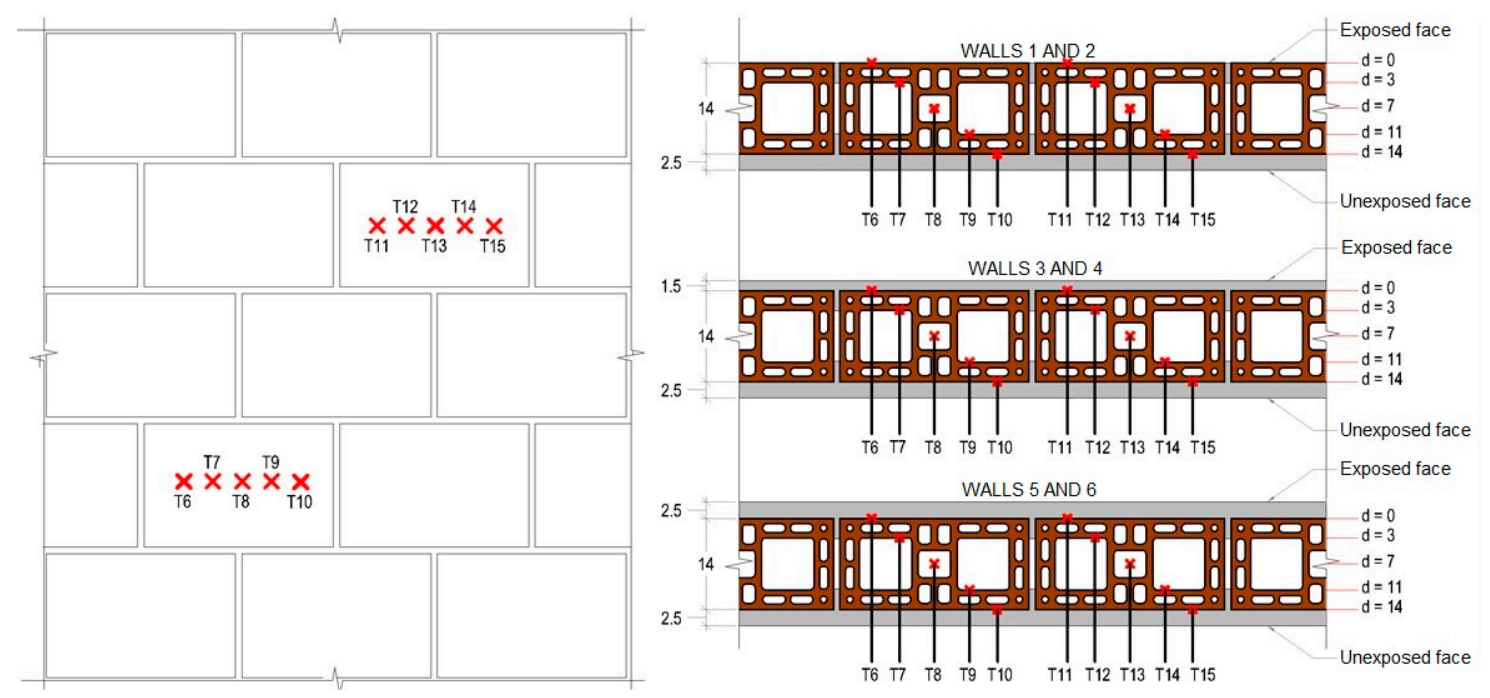

Figure 3. Thermocouple placement along the thickness of the wall.

\subsection{Fire Resistance Tests}

The test apparatus comprised a vertical furnace to which the sample was attached as per Figure 4. It had four burners that used liquefied petroleum gas as fuel, two on each side, without direct contact from the flames on the sample, applied according to the standard ISO 834-1 curve [10]. This apparatus abides by standardized procedures and has been used in other research as well $[1,34,35]$. The horizontal displacement was measured by a mesh of 49 points, with spacing of $50 \mathrm{~cm}$ between each one, covering an area of $9.45 \mathrm{~m}^{2}$. The measurements were performed every $10 \mathrm{~min}$ with the use of the total station equipment. The acceptable limit for horizontal displacement, set by ISO 834 [10], is L/30, where L is the length of constraining extremities. In this study, L was equal to $3150 \mathrm{~mm}$, so the horizontal deflection limit was $105 \mathrm{~mm}$. Every fire resistance test lasted $240 \mathrm{~min}$, except for masonry W2, with a loading of $10 \mathrm{tf} / \mathrm{m}$ and no coating on its internal face, as it failed after $102.5 \mathrm{~min}$ of testing.

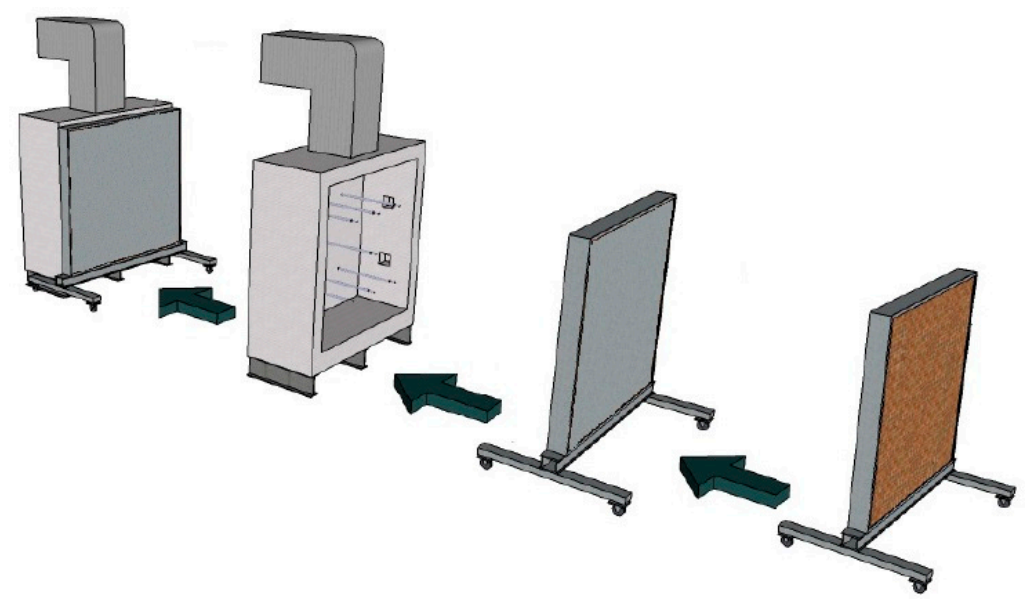

Figure 4. Attaching the samples to the test furnace. 


\section{Results}

\subsection{Sample W1-Unloaded, No Internal Coating}

At $5 \mathrm{~min}$, the sample presented a vertical crack on its center. At the eighth minute, the first signs of smoke appeared on the vertical crack. After the airtightness test, it was noted that the sample remained airtight. At $11 \mathrm{~min}$, another crack appeared, and then the wall retained its integrity up unril $4 \mathrm{~h}$ of testing had occurred. The temperature evolution of wall W1 is depicted in Figure 5. It shows through an exponential equation that the curvature was reduced. Figure 6 then used these data to depict the temperature evolution in the coated clay tiles.

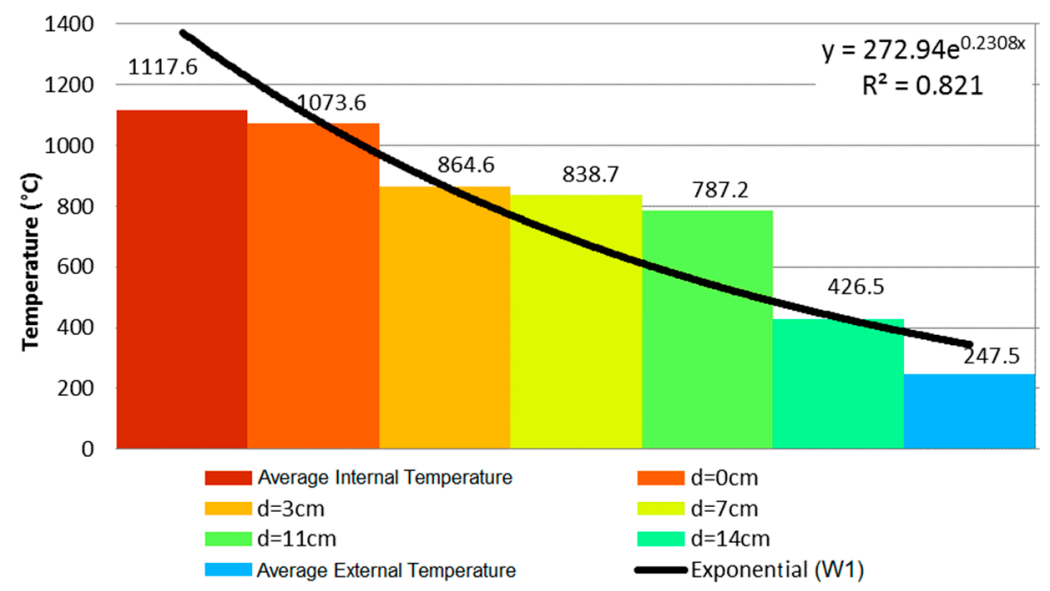

Figure 5. Temperature profile at $240 \mathrm{~min}-\mathrm{W} 1$.

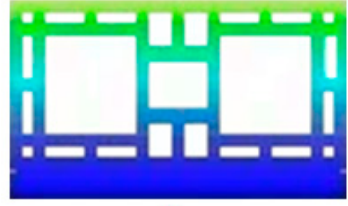

(a)

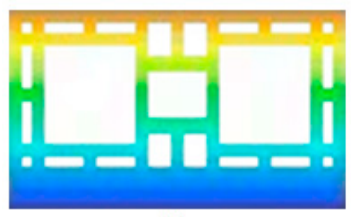

(c)

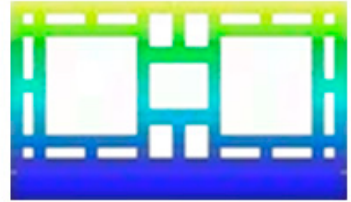

(b)

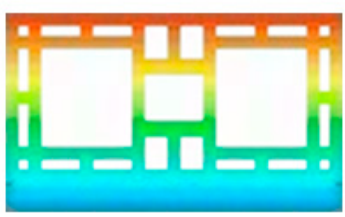

(d)

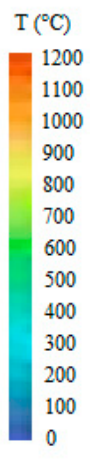

Figure 6. Temperature distribution at (a) $30 \mathrm{~min}$, (b) $60 \mathrm{~min}$, (c) $120 \mathrm{~min}$, and (d) $240 \mathrm{~min}$.

The maximum displacement during the test period was $41 \mathrm{~mm}$, on the fire-exposed face, which occurred at $150 \mathrm{~min}$. It took place in the center of the plane tested, depicted by the blue hue, $35 \mathrm{~mm}$ at $30 \mathrm{~min}$ (Figure 7a) and $41 \mathrm{~mm}$ at $150 \mathrm{~min}$ (Figure 7b). Nguyen and Meftah [9] had carried out tests on clay bricks with a compressive strength of $8 \mathrm{MPA}$ and no loading, and found a displacement of $40 \mathrm{~mm}$ on the exposed face at $30 \mathrm{~min}$. According to these authors, the double bending of the external surface occurs due to differential thermal expansion, which provokes a tensile stress on the exposed face and tends to make it bend towards the fire.

In summary, the sample did remain stable despite the noteworthy passage of hot gases and smoke through the cracks on the unexposed face, which still did not set the cotton wad ablaze, as per procedures determined by ISO 834 [10]. Regarding thermal insulation, the external temperature increased and reached an arithmetic mean of $247.5^{\circ} \mathrm{C}$ at $240 \mathrm{~min}$, with a maximum punctual temperature of $288.1^{\circ} \mathrm{C}$. 


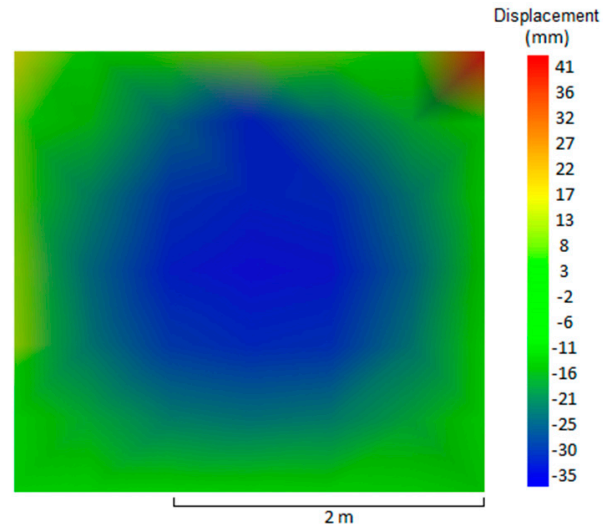

(a)

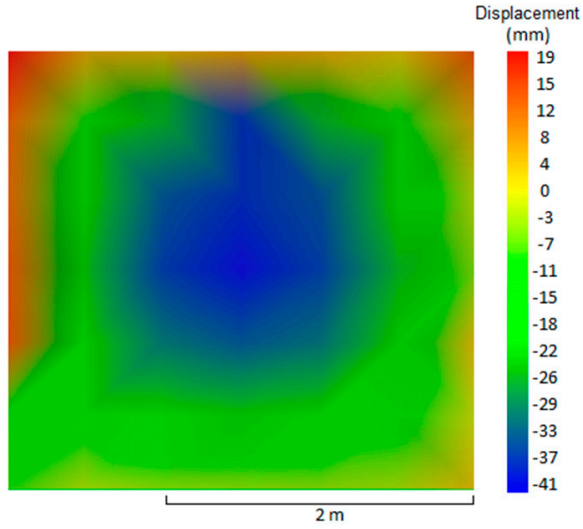

(b)

Figure 7. Displacement of the plane at (a) $30 \mathrm{~min}-\mathrm{W} 1$ and (b) $150 \mathrm{~min}-\mathrm{W} 1$.

\subsection{Sample W2-Reference Sample, Loaded, No Internal Coating}

In the first five minutes of testing, the sample presented no change whatsoever. Then, it presented a vertical crack on its center, on the middle one-third of its height. At 52 min, a horizontal crack appeared (Figure 8a) and, at $102 \mathrm{~min}$, the wall lost its stability (Figure 8b).

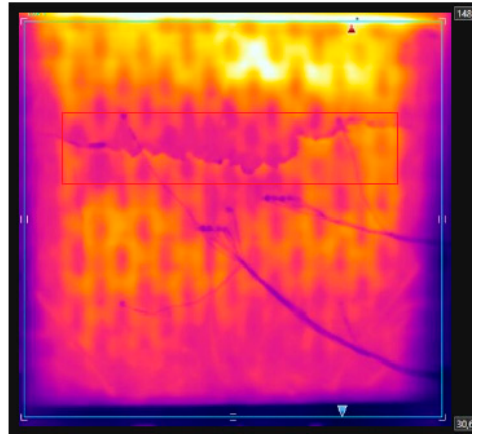

(a)

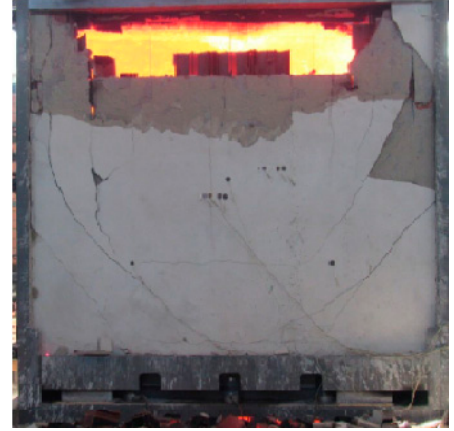

(b)

Figure 8. (a) Horizontal crack at $52 \mathrm{~min}$ and (b) loss of structural stability at $102 \mathrm{~min}$.

The temperature evolution followed the same trend of exponential curve W1, since both walls had the same clay tiles and coating on the unexposed face (Figure 9).

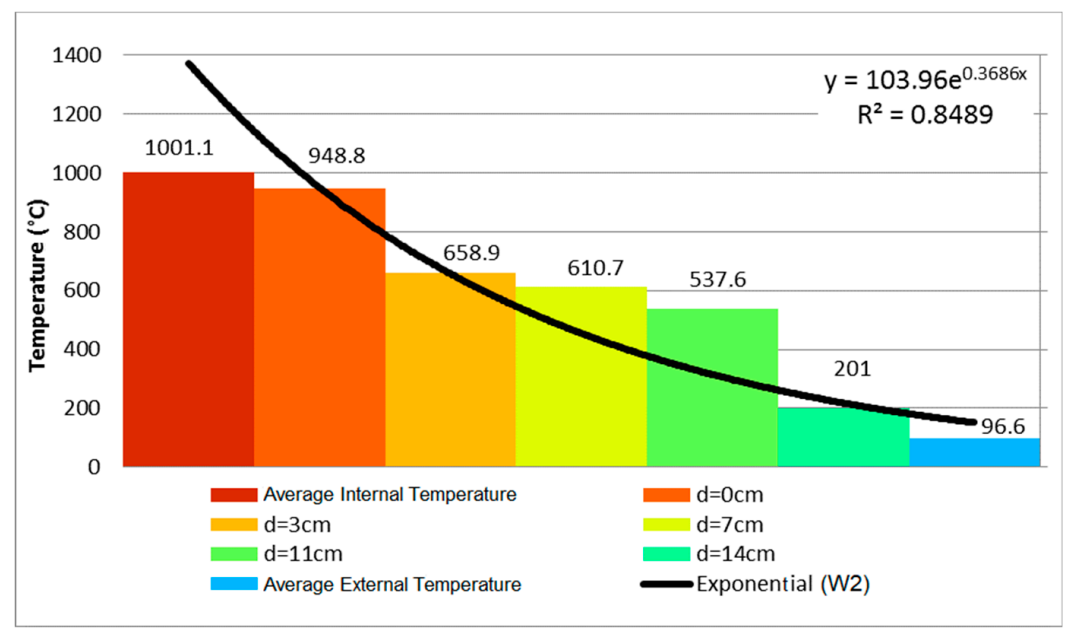

Figure 9. Temperature profile at $102 \mathrm{~min}-\mathrm{W} 2$. 
The wall underwent higher displacement towards the furnace of $32 \mathrm{~mm}$ at $100 \mathrm{~min}$. The displacements over time were lower than those of W1, so it can be assumed that the loading of $10 \mathrm{tf} / \mathrm{m}$ made the wall bend less, due to the greater binding to the test frame. Nguyen and Meftah [9] found lateral displacements of the plane of $23 \mathrm{~mm}$ at $30 \mathrm{~min}$ of testing, $3 \mathrm{~mm}$ smaller than the ones of this study, and $28 \mathrm{~mm}$ at $60 \mathrm{~min}$, the same value, as they analyzed uncoated samples loaded with $13.2 \mathrm{tf} / \mathrm{m}$. In terms of temperature, the maximum average was $96.6^{\circ} \mathrm{C}$ and the punctual maximum was $105^{\circ} \mathrm{C}$ (at $\left.102 \mathrm{~min}\right)$.

\subsection{Sample W3-Unloaded, Internal Coating of $15 \mathrm{~mm}$}

Sample W3 presented a vertical crack on its central part, located on the middle one-third, at $5 \mathrm{~min}$ of testing. At the sixth and ninth minutes, respectively, a horizontal crack appeared to the left of the sample, and so did an oblique crack on the lower edges. The sample remained airtight up until $240 \mathrm{~min}$ had passed. The temperature evolution measured by the thermocouples is shown in Figure 10, measured at $240 \mathrm{~min}$ of testing.

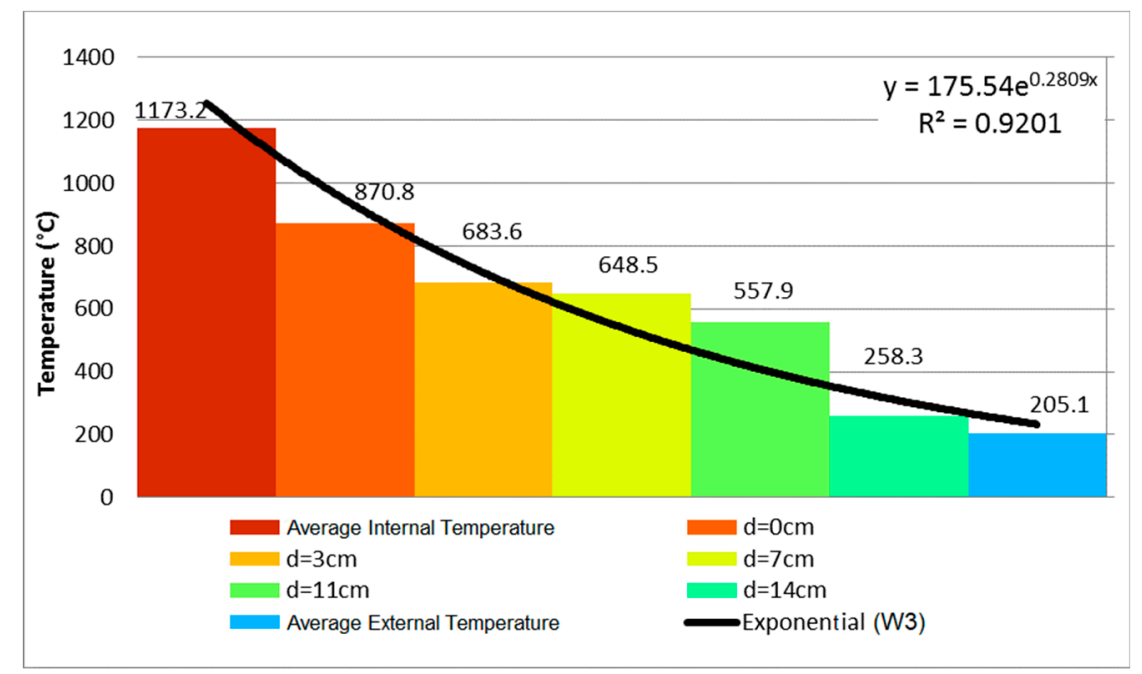

Figure 10. Temperature profile at $240 \mathrm{~min}-\mathrm{P} 3$.

It is noteworthy that the temperature gradient became more intense with the passing of time due to the internal coating of $15 \mathrm{~mm}$, which is the only difference between W1 and W3. Figure 11 then used these data to depict the evolution of the temperature of the coated ceramic tile.

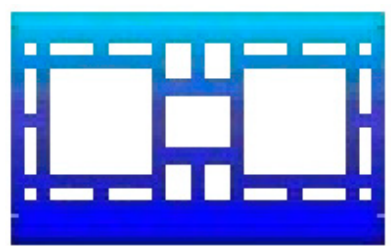

(a)

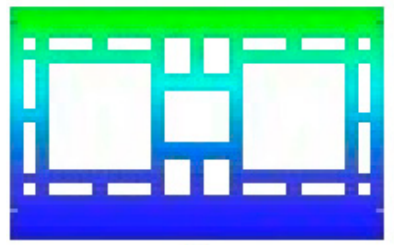

(c)

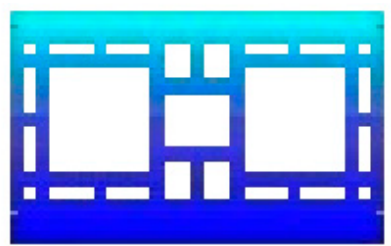

(b)

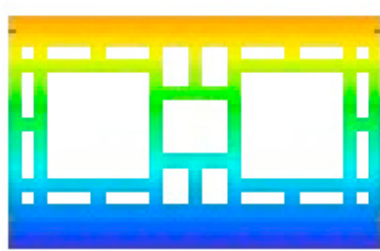

(d)

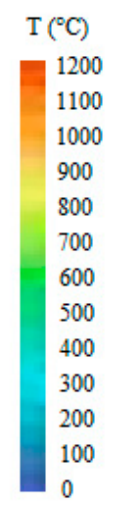

1200
1100
1000
900
800
700
600
500
400
300
200
100
0

Figure 11. Temperature distribution at (a) $30 \mathrm{~min}$, (b) $60 \mathrm{~min}$, (c) $120 \mathrm{~min}$, and (d) $240 \mathrm{~min}$. 
When comparing the temperature evolution of walls W1 and W3, the mortar coating of $15 \mathrm{~mm}$ on the exposed face hindered the heating of the tiles. Between $30 \mathrm{~min}$ and $60 \mathrm{~min}$ there was no significant difference for the unexposed face, as the temperature varied by $9.9^{\circ} \mathrm{C}$. The difference stood out at 120 and $240 \mathrm{~min}$, when the temperature of the external face showed reductions of 72.7 and $42.4{ }^{\circ} \mathrm{C}$, respectively. The decreases in percent were $49.35 \%$ at $120 \mathrm{~min}$ and $17.13 \%$ at $240 \mathrm{~min}$. The maximum displacement during the test was $43 \mathrm{~mm}$ on the exposed face at $30 \mathrm{~min}$ (Figure 12a), while the displacement outside the plane was stabilized at $120 \mathrm{~min}$, varying $2 \mathrm{~mm}$ until reaching $240 \mathrm{~min}$. Initially, the wall bended towards the interior of the furnace, but it backed off during the test without returning to its original position. At $240 \mathrm{~min}$, the final displacement of the plane was $30 \mathrm{~mm}$ on the exposed face (Figure 12b), while that the maximum displacement throughout the entire test took place in the center of the plane, which is represented by the blue hue.

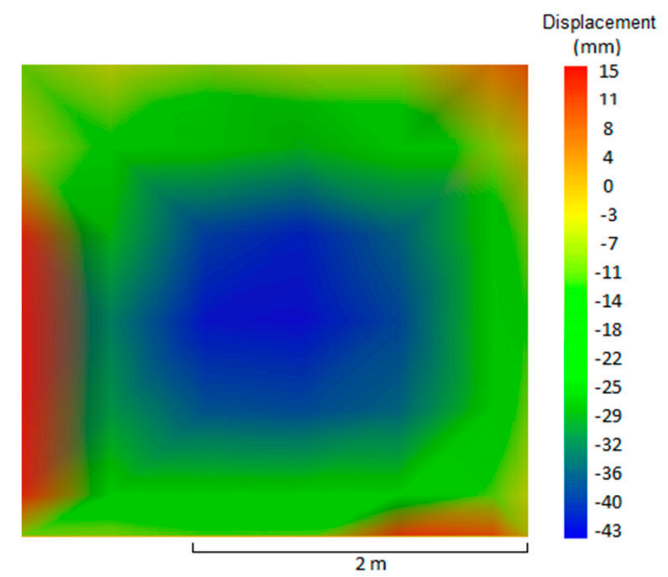

(a)

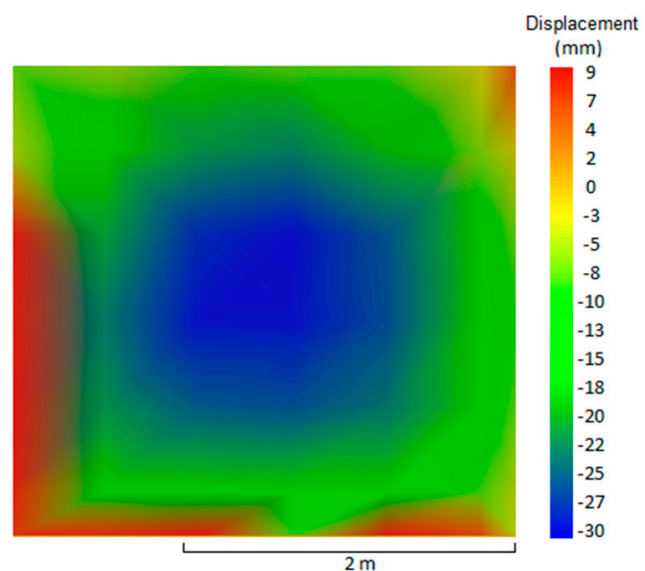

(b)

Figure 12. Displacement of the plane at (a) $30 \mathrm{~min}$ and (b) $240 \mathrm{~min}-\mathrm{W} 3$.

Comparing the displacements of W3 and W1 (Figures 6 and 11), the curvature was similar for both walls, despite sample W3 presenting lower values due to the presence of reinforcement of $15 \mathrm{~mm}$ on the exposed face, which reduced the final lateral displacement by $10 \mathrm{~mm}$ at $240 \mathrm{~min}$. The airtightness of the system was acceptable. In the end, concerning the thermal insulation criterion, there was an increase of the external temperature, reaching the arithmetic mean of $205.1^{\circ} \mathrm{C}$, with a punctual maximum of $228.8^{\circ} \mathrm{C}$.

\subsection{Sample W4-Loaded, Internal Coating of $15 \mathrm{~mm}$}

At 11 min of testing, sample W4 presented oblique cracks on the lower corners and a vertical crack on its center (Figure 13a), similar to the behavior of W2 and W3. The oblique cracks appeared on the corners due to the greater binding and the consequent lower displacement. At $17 \mathrm{~min}$, the first signs of smoke arose from the vertical crack (Figure 13b). The temperature evolution is depicted in Figure 14, which details the 240 min of testing.

Nadjai et al. [20] stated that load-bearing samples tend to deform and present vertical cracks, on both central area and middle point of the edges, thereby agreeing with the behavior observed in this study (Figure 13a).

As the test went on, the temperature variation along the thickness decreased over time. Based on the results of thermal gradient and thermographic camera, it was noted that the temperature of the clay tile was higher in the first few minutes, compared to the other coated samples, owing to the spalling of the coating on the inner side, of $15 \mathrm{~mm}$, which allowed heat to act directly over the substrate. The values obtained were close to those pertaining to sample W1, with no internal coating. At $30 \mathrm{~min}$, the first signs of spalling came about, as shown by the orange coloring on the top right side of Figure 15a, 
which was proven when the sample was detached from the furnace (Figure 15b). First there was the spalling of the coating, and then the chipping of the clay tile.

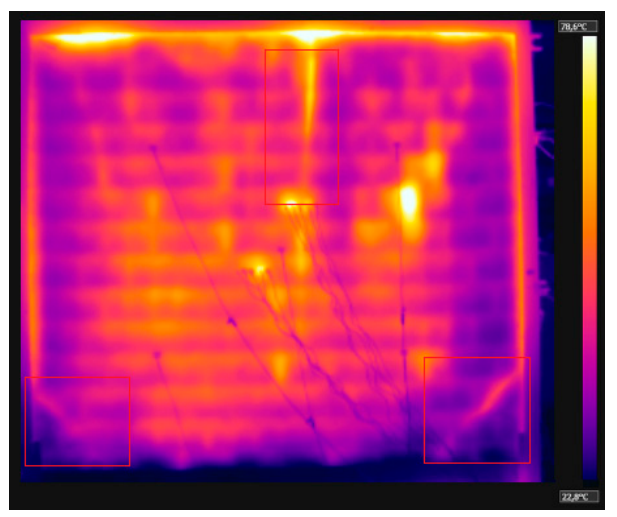

(a)

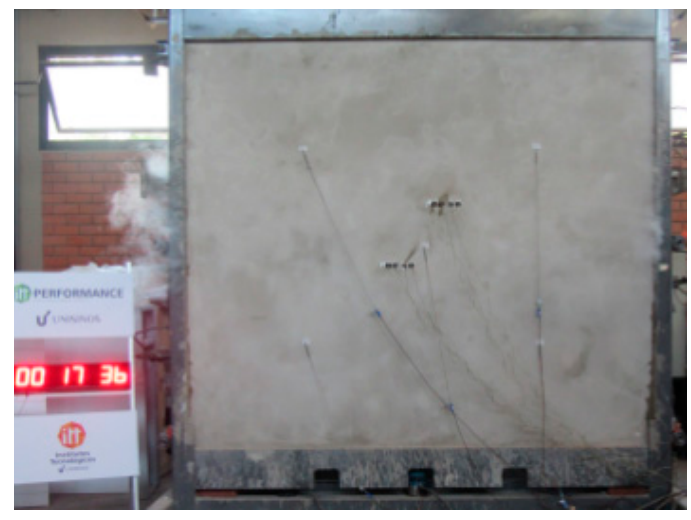

(b)

Figure 13. (a) Vertical and oblique cracks; (b) Smoke coming out of the vertical crack and its surroundings.

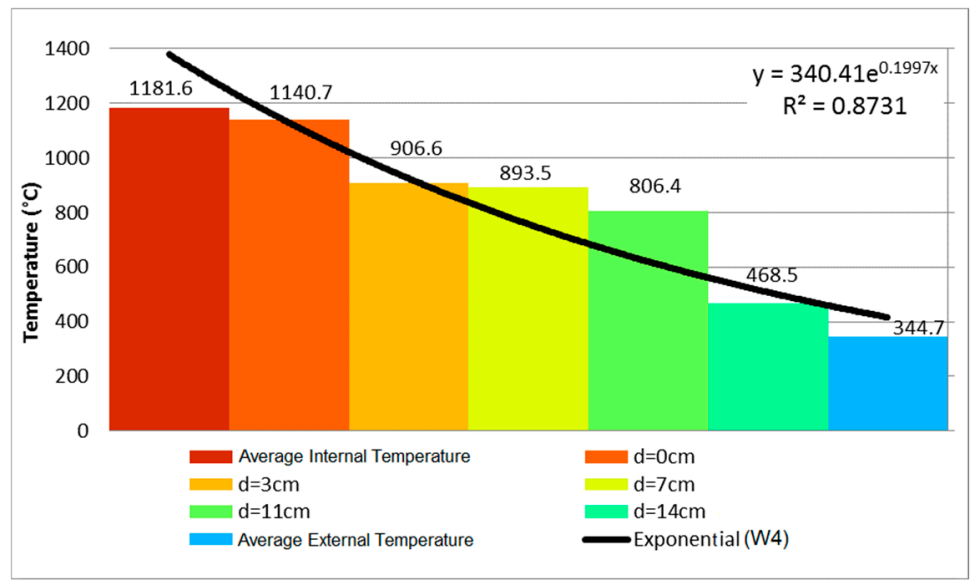

Figure 14. Temperature profile at $240 \mathrm{~min}-\mathrm{W} 4$.

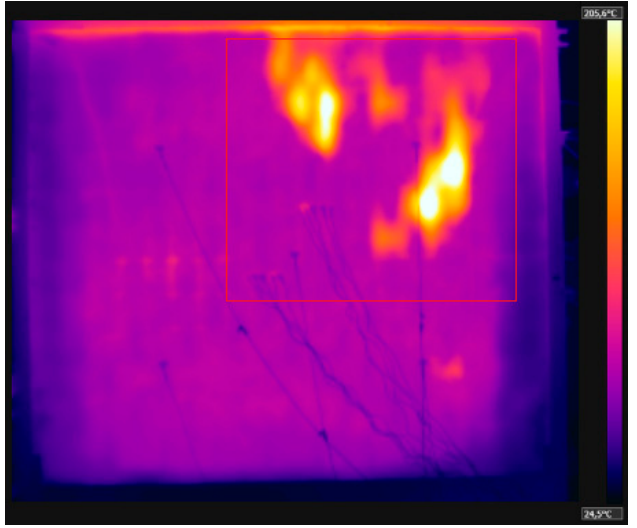

(a)

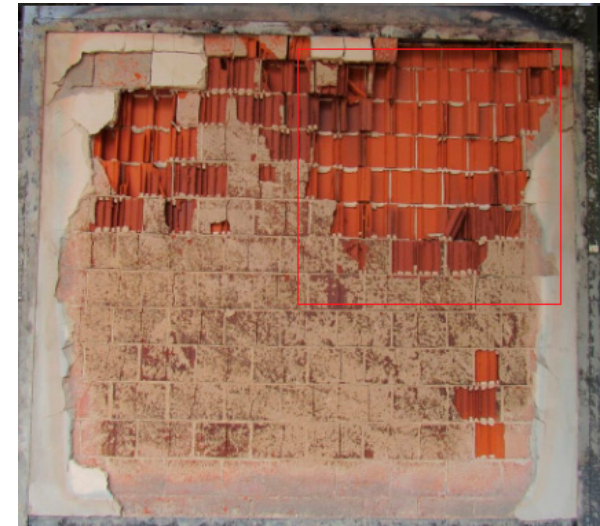

(b)

Figure 15. (a) Evidence of spalling of the coating on the inner side (b) sample after the fire resistance test.

According to Nguyen and Meftah [9], chipping is a consequence of second order effects that result from the change of eccentricity of the wall, considering that the materials of the exposed face, clay tile and mortar, lose their mechanical properties. The wall initially bends towards the fire, and, during the 
test, it returns to the unexposed side, although it does not return to the starting position. After $240 \mathrm{~min}$ of testing, the final displacement of the plane was $20 \mathrm{~mm}$ to the unexposed side on the upper half of the sample, behavior similar to that of W2 but with higher values, since W2 had no mortar coating on the inner side.

In the experiment of Nguyen and Meftah [9], the sample underwent plane displacement of $14 \mathrm{~mm}$ towards the exposed side at $125 \mathrm{~min}$. According to these authors, the simple bending of the external face was a result of differential thermal expansion, as tensile stresses act on the exposed side and provoke the bending towards the fire, despite the restraint on the top and bottom supports. Nevertheless, the sample presented stable behavior and remained airtight throughout the entirety of the test, even with displacements of $21 \mathrm{~mm}$ at $90 \mathrm{~min}$. As for thermal insulation, there was an increase to the external temperature, with arithmetic mean of 344.7 and punctual maximum of $363.6^{\circ} \mathrm{C}$.

\subsection{Sample W5-Unloaded, Internal Coating of $25 \mathrm{~mm}$}

During the first $10 \mathrm{~min}$, nothing happened to sample W5. Then it presented oblique cracks on the lower corners, where displacement was smaller due to the restraint. At $60 \mathrm{~min}$, small stains appeared around the sample, which resulted from moisture. Their appearance was explained by the noteworthy coating thickness of $25 \mathrm{~mm}$ on the exposed side, which hindered the sample's loss of water. Throughout the $240 \mathrm{~min}$ of the fire resistance test, there was no evidence of smoke or hot gases being expelled from the cracks. The temperature measured at $120 \mathrm{~min}$ by the average of five points was $78.8^{\circ} \mathrm{C}$. The temperature evolution measured by the thermocouples of W5 is shown in Figure 15, after 240 min of testing.

The variation of the temperature along the thickness was smaller due to the coating of $25 \mathrm{~mm}$ on the exposed face. Wall W3 behaves similarly, despite its coating being $10 \mathrm{~mm}$ thinner. Figure 16 uses these results to depict the temperature evolution of the coated clay tile. Figure 17 shows the Temperature distribution of the tile at different times of exposure.

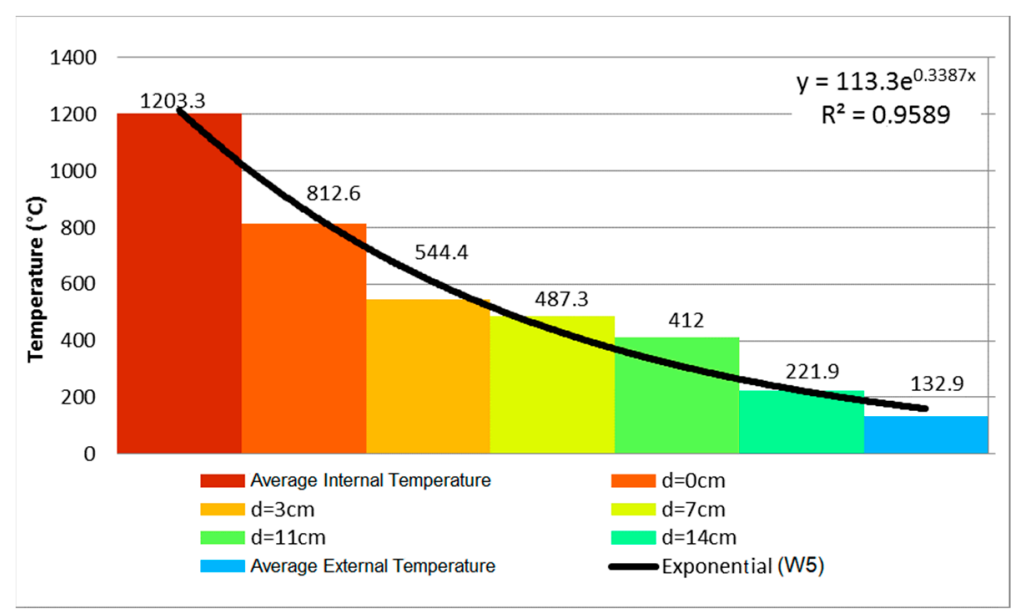

Figure 16. Temperature profile at $240 \mathrm{~min}-\mathrm{W} 5$.

Comparing the evolution of temperature along the thickness of samples W1, W3, and W5, it can be stated that the mortar coating of $25 \mathrm{~mm}$ on the exposed face hindered the heating of the clay tile. In the first $60 \mathrm{~min}$, the unexposed face presented a temperature difference of $9.6^{\circ} \mathrm{C}$, although the difference became more significant at 120 and $240 \mathrm{~min}$ as decreased by 68.5 and $114.6^{\circ} \mathrm{C}$, respectively. In other words, the temperature decrease on the unexposed face was $46.51 \%$ at $120 \mathrm{~min}$ and at $46.30 \%$ at $240 \mathrm{~min}$. 


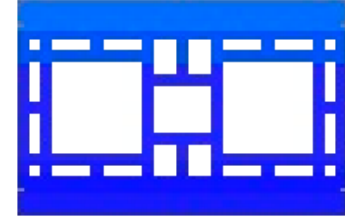

(a)

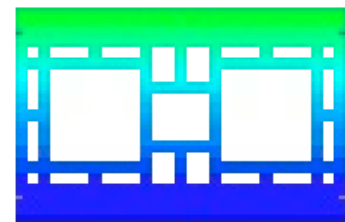

(c)

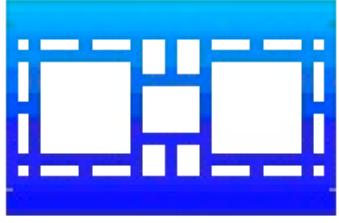

(b)

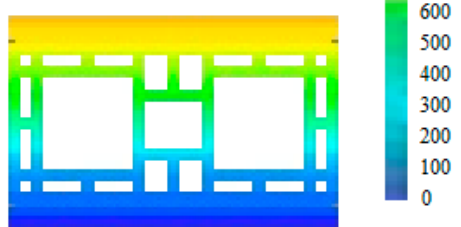

(d)

Figure 17. Temperature distribution of the tile at (a) $30 \mathrm{~min}$, (b) $60 \mathrm{~min}$, (c) $120 \mathrm{~min}$ and (d) $240 \mathrm{~min}$.

The maximum displacement of wall W5 was $39 \mathrm{~mm}$ on the exposed face at $30 \mathrm{~min}$ of testing, which remained stable from $120 \mathrm{~min}$ to the end of the test at $240 \mathrm{~min}$, when the final displacement of the plane was $29 \mathrm{~mm}$. The displacements bore by W5 were similar to those of W1 due to the presence of coating of $25 \mathrm{~mm}$ on the exposed face, with a reduction of $11 \mathrm{~mm}$ in the final displacement, going from $40 \mathrm{~mm}$ to $29 \mathrm{~mm}$.

During the $240 \mathrm{~min}$ of testing, the sample presented stable behavior. Regarding the airtightness of the system, there was no evidence of the passage of hot gases or smoke to the exterior of the wall through the oblique cracks. As for thermal insulation, there was an increase of external temperature, as it reached the average of $132.9^{\circ} \mathrm{C}$ with a punctual maximum of $156.2^{\circ} \mathrm{C}$.

\subsection{Sample W6-Loaded, Internal Coating of $25 \mathrm{~mm}$}

At $16 \mathrm{~min}$, oblique cracks appeared on the lower corners, similar to the behavior of the other samples. At $57 \mathrm{~min}$, small stains appeared around the sample due to moisture. This phenomenon was also identified during the test of W5 at $60 \mathrm{~min}$. This happened because the walls had mortar coating of $25 \mathrm{~mm}$ on the exposed side, which hindered the loss of exceeding water during the 56 days of curing. At $80 \mathrm{~min}$, the spalling of the mortar on the inner side was noted, as Figure 18a depicts. There were noteworthy differences in the color hues captured by the thermographic camera, which were later proved by Figure 18b. The temperature evolution measured by the thermocouples attached to W6 is shown in Figure 19, recorded after 240 min of testing.

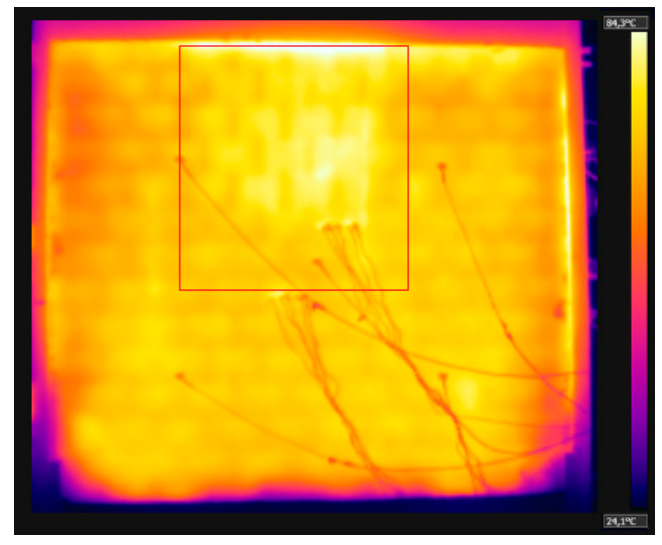

(a)

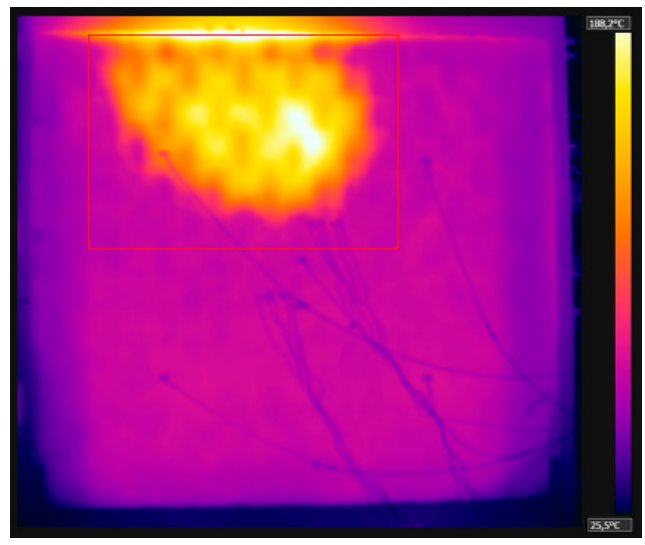

(b)

Figure 18. (a) Spalling begins_-80 $\mathrm{min}$, and (b) spalling ends—-240 $\mathrm{min}$. 


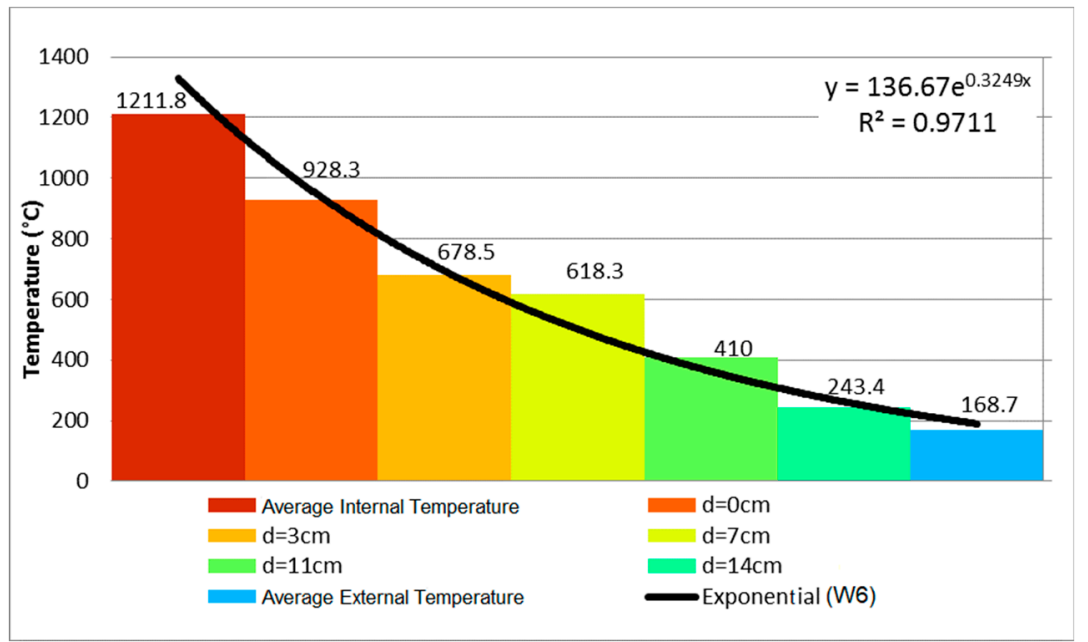

Figure 19. Temperature profile at $240 \mathrm{~min}-\mathrm{P} 6$.

Comparing the evolution of temperature along the thickness of walls $\mathrm{W} 2, \mathrm{~W} 4$, and $\mathrm{W} 6$, it is possible to conclude that the mortar coating of $25 \mathrm{~mm}$ on the exposed face hindered the heating of the clay tile. In the first $60 \mathrm{~min}$, the axis of the wall presented a reduction of $75.58 \%$, going from $426.8^{\circ} \mathrm{C}$ to $104.2^{\circ} \mathrm{C}$, that is, a decrease of $322.6^{\circ} \mathrm{C}$. In spite of the difference of $10 \mathrm{~mm}$ in the internal coating of W4 and $\mathrm{W} 6$, the difference on the external face was $176^{\circ} \mathrm{C}$, going from $344.7^{\circ} \mathrm{C}$ to $168.7^{\circ} \mathrm{C}$, representing a decrease of $51.06 \%$ on the unexposed face. Therefore, the coating affected the performance of the wall in a positive way.

W6 presented maximum displacement of $24 \mathrm{~mm}$ towards the exposed side at $180 \mathrm{~min}$. The displacement stabilized at $120 \mathrm{~min}$ and remained so until the end of the test at $240 \mathrm{~min}$, when the final displacement of the plane was $23 \mathrm{~mm}$ towards the furnace. Wall W6 presented the smallest displacements compared to the other walls due to the combination of its thickness of $25 \mathrm{~mm}$ and the effect of loading, which restrained the displacement of the wall.

During the $240 \mathrm{~min}$ of testing, W6 presented stable behavior as it retained its structural stability. Regarding the airtightness of the system, there were no signs of the passage of gases or smoke to the outer side of the wall through the oblique cracks. As for thermal insulation, it was noted that the external temperature increased and achieved a mean of $168.7^{\circ} \mathrm{C}$ with a punctual maximum of $231.5^{\circ} \mathrm{C}$.

\section{Discussion}

The comparative analysis between samples is based on Table 5, which summarizes the manifestations during the tests.

Table 5. Data compilation.

\begin{tabular}{cccccc}
\hline Sample & $\begin{array}{c}\text { Internal } \\
\text { Coating }(\mathbf{m m})\end{array}$ & $\begin{array}{c}\text { Loading } \\
\mathbf{( t f} / \mathbf{m})\end{array}$ & $\begin{array}{c}\text { Maximum } \\
\text { Displacement }(\mathbf{m m})\end{array}$ & $\begin{array}{c}\text { Maximum Average } \\
\text { Temperature }\left({ }^{\circ} \mathbf{C}\right)\end{array}$ & $\begin{array}{c}\text { Fire-resistance } \\
\text { Rating (FRR) }\end{array}$ \\
\hline W1 & 0 & 0 & 41 & 247.5 & 131 \\
W2 & 0 & 10 & 32 & 96.6 & 81 \\
W3 & 15 & 0 & 43 & 205.1 & 208 \\
W4 & 15 & 10 & 21 & 344.7 & 142 \\
W5 & 25 & 0 & 39 & 132.9 & 240 \\
W6 & 25 & 10 & 24 & 168.7 & 221 \\
\hline
\end{tabular}

The analysis with a focus on the deformations of the samples shows that the values were higher for unloaded samples, when comparing the same coating and the absence of load. This behavior has already been reported by the literature [25], indicating that non-load beaning walls tend to present greater central bending, in contrast with load-bearing samples that present vertical deformations on 
the central axis and on the central point of each of their sides. Concerning the loading, its influence was noted when comparing samples W1 with W2, W3 with W4, and W5 with W6, bearing in mind that higher fire-resistance ratings (FRR) were attained by unloaded samples, along with higher displacement. Figure 20 shows the distribution of temperature over time for uncoated samples with variation in terms of load application.

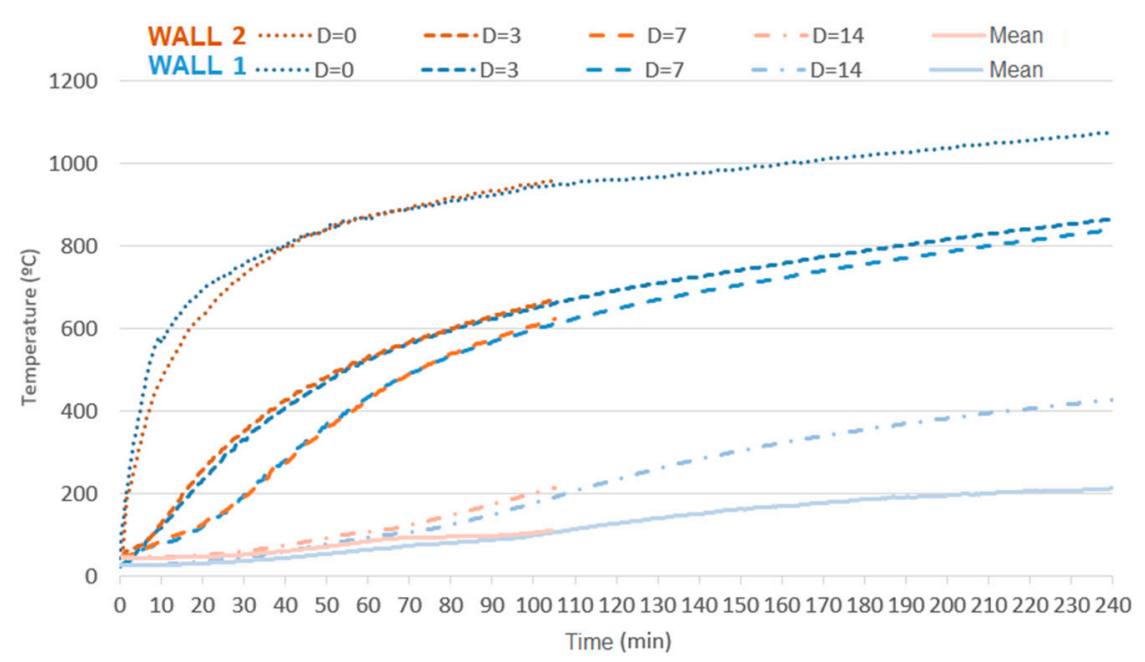

Figure 20. Influence of loading on masonries with no coating on the fire-exposed face.

Samples W1 and W2 demonstrate the relevance of having the fire-exposed face of a load-bearing masonry coated, due to the structural failure of sample W2 at $102 \mathrm{~min}$. Sample W1, which was also uncoated but not loaded, performed better as it retained its structural stability up to $240 \mathrm{~min}$. This event is possibly connected to the direct exposure of clay to temperatures close to those of its production process, as its microstructure changes at temperatures above $950{ }^{\circ} \mathrm{C}$ [24]. Such changes may have compromised the load-bearing capacity of the sample, as it bore load beyond its own weight and failed. Figure 21 presents the influence of loading on samples with a coating of $15 \mathrm{~mm}$.

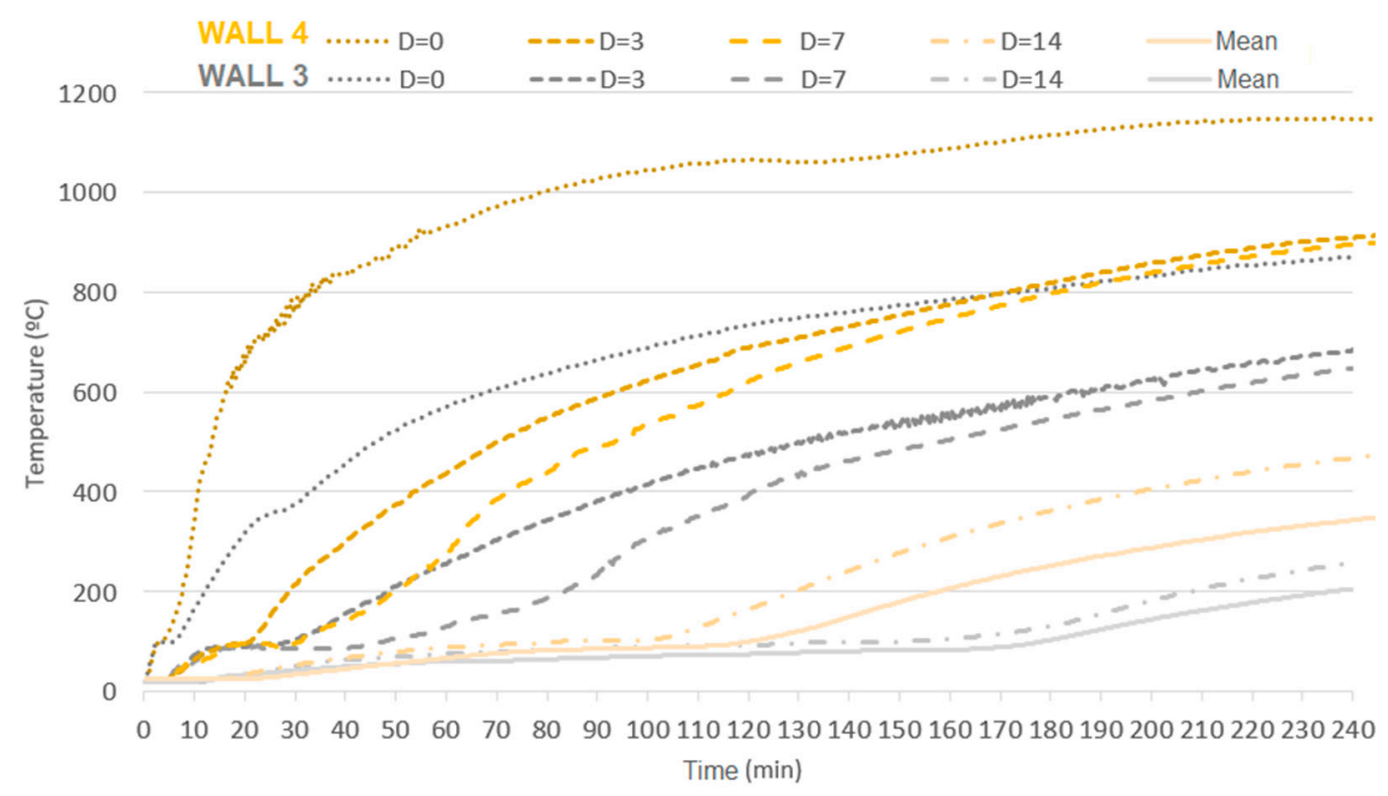

Figure 21. Development of the temperature over time on masonries with $15 \mathrm{~mm}$ of coating on the fire-exposed face, without (W3) and with (W4) application of load. 
It is notable, mainly for the thermocouples attached to the inner face of the tiles $(d=0)$ that temperature development is more intense on load-bearing samples. Such a fact arises from the higher degree of cracking or even spalling on the masonry owing to the aforementioned changes in microstructure and loading. Figure 22 demonstrates that the increased coating and the consequent increased thermal inertia allowed the tiles to reach lower temperatures, which in turn had less impact, smoothing the effect of loading as the temperatures that change load-bearing capacity were not reached.

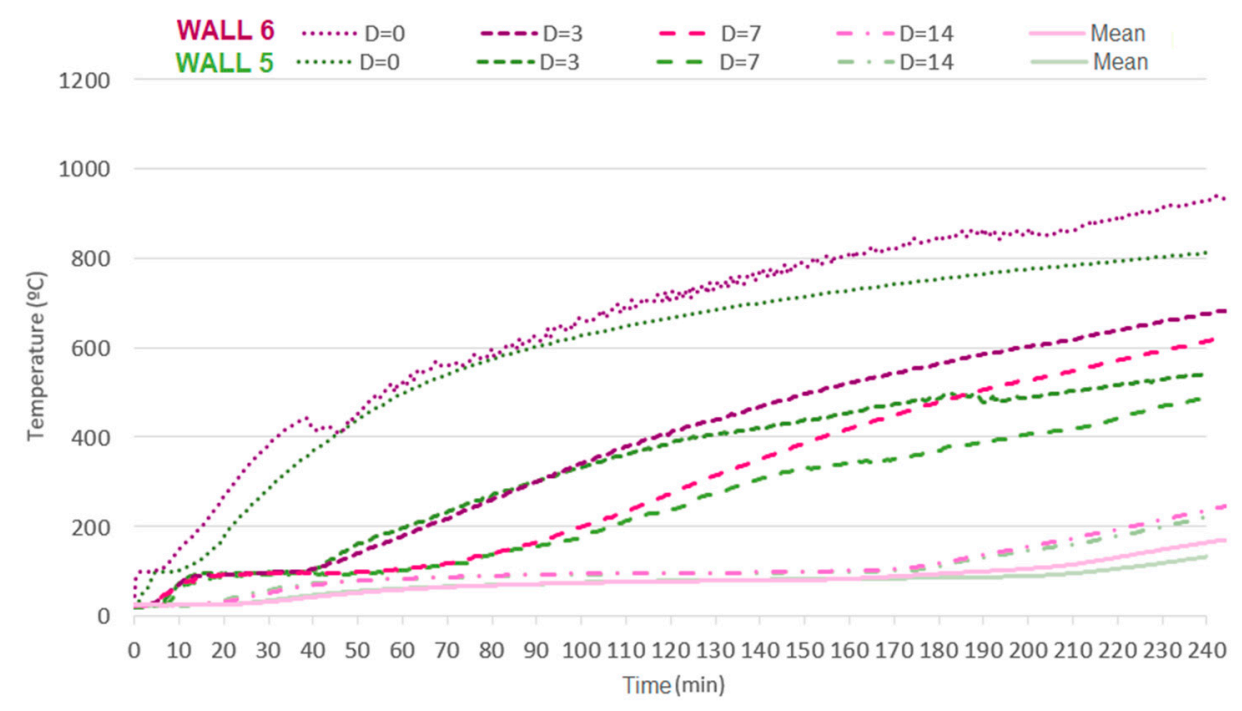

Figure 22. Influence of loading on masonries with $25 \mathrm{~mm}$ of coating on the fire-exposed face.

Figure 23 compares two extreme samples regarding the use of coating, that is, W1 with no coating, and W5 with coating of $25 \mathrm{~mm}$ on the fire-exposed face, in order to analyze unloaded samples.

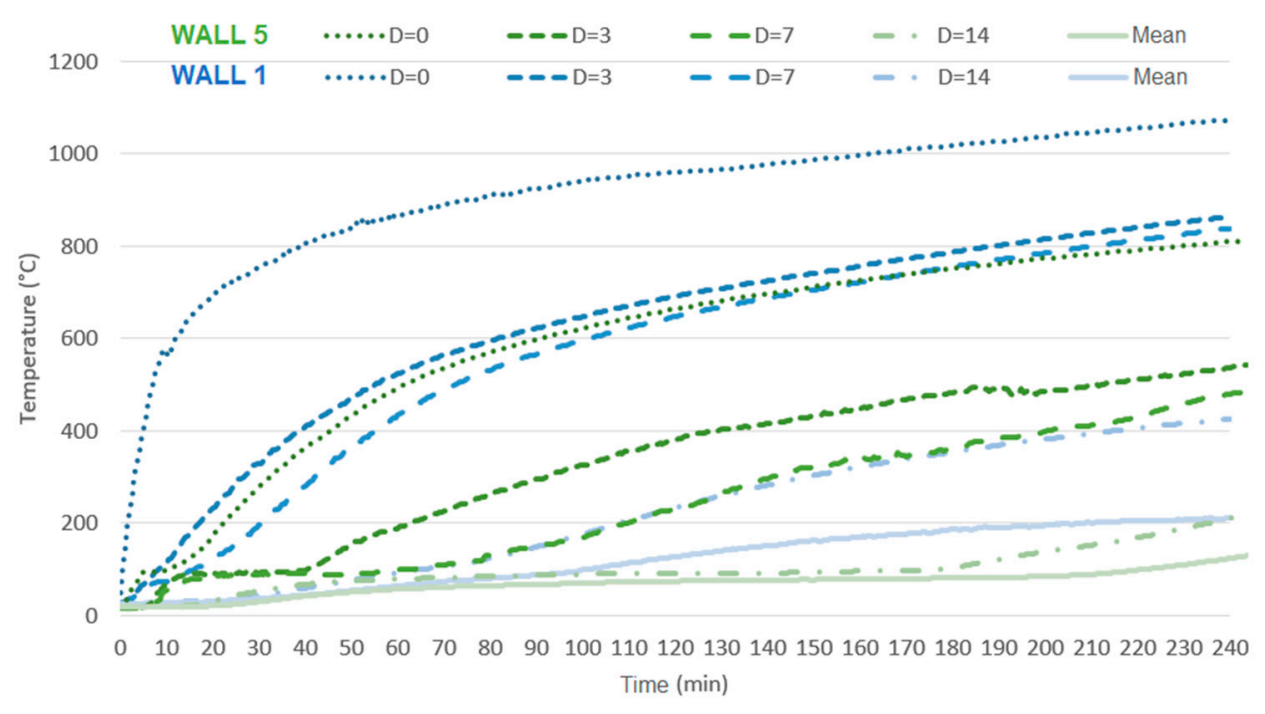

Figure 23. Influence of the addition of $25 \mathrm{~mm}$ of coating on the fire-exposed face.

From this figure, it is possible to assert that all depths of analysis attained improvements with regards to the attenuation of the maximum temperature. The impact was more critical for depths of 0 and $3 \mathrm{~cm}$, with respect to the inner face of the tile. The improvement of the unexposed face was $17 \%$ and $46 \%$, with coatings of $15 \mathrm{~mm}$ and $25 \mathrm{~mm}$, respectively. According to ACI TMS 216.1 [36], adding a coating of $19 \mathrm{~mm}$ of cement and sand mortar over the screen, a procedure similar to the one performed on $\mathrm{W} 4$, should provide a gain of $20 \mathrm{~min}$ to fire resistance in comparison with the uncoated sample 
(W2). Moreover, adding $25.4 \mathrm{~mm}$ under the same conditions should increase this benefit to $30 \mathrm{~min}$. The values obtained in this study surpass that expectation, since the addition of $15 \mathrm{~mm}$ compared to the uncoated sample provided an increase from 81 to $142 \mathrm{~min}$ of fire resistance, and from 81 to $221 \mathrm{~min}$ with $25 \mathrm{~mm}$.

\section{Conclusions}

The experimental procedure results led to the conclusion that the unloaded sample that achieved the best performance with respect to the fire-resistance rating (FRR) was W5 (25 mm of coating on both faces), with an FRR of $240 \mathrm{~min}$, namely, meeting the requirements of airtightness, structural stability and thermal insulation within this timespan. The samples tended to undergo decreased lateral displacements of the plane as their total thickness increased.

The loaded sample that showed the best performance for FRR was W6 (25 mm of coating on both faces), meeting the requirements of structural stability and airtightness while losing its thermal insulation at $221 \mathrm{~min}$. Thus, coating thickness improved the performance of the masonry during the fire resistance test, as the temperature on the external face decreased by $46.3 \%$, going from $247.5^{\circ} \mathrm{C}$ to $132.9^{\circ} \mathrm{C}$ on W5. W6 presented a decrease of $51.05 \%$ after the addition of $10 \mathrm{~mm}$ of coating on its exposed face, going from $15 \mathrm{~mm}$ to $25 \mathrm{~mm}$.

Comparing same sample types with and without loading, it can also be concluded that the unloaded samples were the ones to present maximum displacements between 43 and $39 \mathrm{~mm}$ during the fire resistance test. This became clear as there were no restraints on the top and bottom parts, hence allowing the plane to bend with double curvature. On the other hand, the loaded samples underwent deformations on the upper part with values between 26 and $23 \mathrm{~mm}$, most likely due to the restraint of the top and bottom edges caused by the loading, hence forcing the simple curvature bending.

This study had exploratory and explanatory natures, and was developed because the market lacks standards that guide the design of this type of system in these conditions, whereas the already-existing guidelines do not address load-bearing masonries and the wide range of compositions involved. By performing tests on different types of samples, it was possible to note peculiar behaviors among the typologies evaluated. Both the presence of loading and mortar coating thickness turned out to have an influence on the fire resistance of load-bearing masonry systems. It was noted that only sample W2 underwent a loss of stability and airtightness (wall with loading and no internal coating) as well failing at $102 \mathrm{~min}$, hence forcing the sudden end of the test. The event of spalling caused by the loss of the internal part of the clay tiles was detected during the test with the aid of the thermographic camera. This manifestation was predominant for load-bearing samples. Also, the presence of loading does influence the direction towards which the sample bends.

Author Contributions: R.P.d.S.: designed the experiment procedure; F.P.: was responsible for results analysis and text correct; G.L.P.: has extensive knowledge in test analysis techniques, has instrumented all samples and collected results; A.M.G.: was responsible for results and text first version; R.C.: was responsible to check the instrumentation and conduce the lab tests. V.M.d.M.: helped with literature review and results analysis. B.F.T.: revisor and supervisor professor.

Funding: This research received no external funding.

Conflicts of Interest: The authors declare there is no conflict of interest.

\section{References}

1. Gil, A.; Pacheco, F.; Christ, R.; Bolina, F.L.; Khayat, K.H.; Tutikian, B.F. Comparative study of concrete panels' fire resistance. Aci Mater. J. 2017, 114, 755-762. [CrossRef]

2. Buchanan, A.H.; Abu, A.K. Structural Design for Fire Safety; Wiley: Chichester, UK, 2017.

3. Silva, V.P. Projeto de Estruturas de Concreto em Situação de Incêndio; Blücher: São Paulo, Brazil, 2012.

4. Martinho, E.; Dionísio, A. Assessment Techniques for Studying the Effects of Fire on Stone Materials: A Literature Review. Int. J. Archit. Herit. 2018. [CrossRef] 
5. Guo, Z.; Shi, X. Experiment and Calculation of Reinforced Concrete at Elevated Temperatures; Elsevier: London, UK, 2011.

6. Mitidieri, M.L. O comportamento dos materiais e componentes construtivos diante do fogo - reação ao fogo. In A Segurança Contra Incêndio No Brasil Brasil; Seito, A.I., Gill, A.A., Pannoni, F.D., Ono, R., Silva, S.B., Del Carlo, U., Pignatta e Silva, V., Eds.; Projeto Editora; Blücher: São Paulo, Brazil, 2008; pp. 55-75.

7. Marcatti, J.; Coelho Filho, H.S.; Berquó Filho, J.E. Compartimentação e afastamento entre edificações. In $A$ Segurança Contra Incêndio No Brasil; Seito, A.I., Gill, A.A., Pannoni, F.D., Ono, R., Silva, S.B., Del Carlo, U., Pignatta e Silva, V., Eds.; Projeto Editora; Blücher: São Paulo, Brazil, 2008; pp. 169-179.

8. Al-Hadhrami, L.M.; Ahmad, A. Assessment of thermal performance of different types of masonry bricks used in Saudi Arabia. Appl. Therm. Eng. 2009, 29, 1123-1130. [CrossRef]

9. Nguyen, T.D.; Meftah, F. Behavior of hollow clay brick masonry walls during fire. Part 2: 3D finite element modeling and spalling assessment. Fire Saf. J. 2014, 66, 35-45. [CrossRef]

10. International Organization for Standardization (ISO). ISO 834-1: Fire-Resistance Tests_Elements of Building Construction_Part 1: General Requirements; ISO: Geneva, Switzerland, 1999.

11. Associação Brasileira de Normas Técnicas. NBR 10636: Paredes divisórias sem função estrutural- Determinação da resistência ao fogo- Método de ensaio; NBR: Rio de Janeiro, Brazil, 1989.

12. Associação Brasileira de Normas Técnicas. NBR 5628: Componentes construtivos estruturais-Determinação da resistência ao fogo. Rio de Janeiro, 2001; NBR: Rio de Janeiro, Brazil, 1989.

13. Japanese Standards Association (JSA). JIS A 1304: Method of Fire Resistance Test for Structural Parts of Buildings; JSA: Tokyo, Japan, 1994.

14. American Society for Testing Materials (ASTM). ASTM E119-16a: Standard Test Methods for Fire Tests of Building Construction and Materials; ASTM International: West Conshohocken, PA, USA, 2016.

15. Gomez-Heras, M.; McCabe, S.; Smith, B.J.; Fort, R. Impacts of Fire on Stone-Built Heritage. J. Archit. Conserv. 2009, 15, 47-58. [CrossRef]

16. Rosemann, F. Resistência ao Fogo de Paredes de Alvenaria Estrutural de Blocos Cerâmicos Pelo Critério de Isolamento Térmico. Master's Thesis, Universidade Federal de Santa Catarina (UFSC), Florianópolis, Brazil, 2011.

17. Seito, A.I.; Gill, A.A.; Pannoni, F.D.; Bento da Silva, R.O.S.; Carlo, U.D.; Silva, V.P.E. A SegurançA Contra Incêndio no Brasil; Blücher: São Paulo, Brazil, 2008.

18. ONO, R. Parâmetros para garantia da qualidade do projeto de segurança contra incêndio em edifícios altos. Ambiente Constr. 2007, 7, 97-113.

19. Brick Industry Association (BIA). Technical Note 16: Fire Resistance of Brick Masonry; The Brick Industry Association: Reston, VA, USA, 2008.

20. Nadjai, A.; O'Gara, M.; Ali, R.; Jurgen, R. Compartment masonry walls in fire situations. Fire Technol. 2006, 42, 211. [CrossRef]

21. Nguyen, T.D.; Meftah, F.; Chammas, R.; Chammas, A. The behaviour of masonry walls subjected to fire: Modelling and parametrical studies in the case of hollow burnt-clay bricks. Fire Saf. J. 2009, 44, 629-641. [CrossRef]

22. Beall, C. Masonry Design and Detailing: For Architects, Engineers, and Contractors, 4th ed.; McGraw-Hill Companies: New York, NY, USA, 1997.

23. Ayala, R. Mechanical Properties and Structural Behaviour of Masonry at Elevated Temperatures. Ph.D. Thesis, University of Manchester, Manchester, UK, 2011.

24. RIGÃO, A.O. Comportamento de Pequenas Paredes de Alvenaria Estrutural Frente a Altas Temperaturas. Master's Thesis, Universidade Federal de Santa Maria, Santa Maria, Brazil, 2012.

25. Nadjai, A.; O'gara, M.; Ali, F. Finite element modelling of compartment masonry walls in fire. Comput. Struct. 2003, 81, 1923-1930. [CrossRef]

26. Ingham, J.P. Forensic engineering of fire-damaged concrete structures. In Forensic engineering: From failure to understanding; Neale, B.S., Ed.; Thomas Telford Publishing: London, UK, 2009; pp. 393-402.

27. Ehrenbring, H.Z.; Quinino, U.; Oliveira, L.S.; Tutikian, B.F. Experimental method for investigating the impact of the addition of polymer fibers on drying shrinkage and cracking of concrete. Struct. Concr. 2019, 20, 1064-1075. [CrossRef] 
28. Pacheco, F.; Souza, R.; Christ, R.; Rocha, C.; Silva, L.; Tutikian, B.F. Determination of volume and distribution of pores of concretes according to different exposure classes through 3D microtomography and mercury intrusion porosimetry. Struct. Conc. 2018, 19, 1419-1427. [CrossRef]

29. Silva, F.A.N.; Oliveira, R.A.; Sobrinho, C.W.P. Influence of the mortar covering on the strength of clay masonry walls. In XXXIII Jornadas Sudamericanas de Ingenieria Estructural; Asaee: Santiago, Chile, 2008.

30. American society for Testing Materials (ASTM). ASTM C 150 - 19a Standard Specification for Portland Cement; ASTM International: West Conshohocken, PA, USA, 2019.

31. British Standard. EN 933-1: Tests for geometrical properties of aggregates Part 1- Sieving method; BSI: London, UK, 2012.

32. American Society for Testing Materials (ASTM). ASTM C 652 - 19 Standard Specification for Hollow Brick (Hollow Masonry Units Made from Clay or Shale); ASTM: West Conshohocken, PA, USA, 2019.

33. Georgantas, A.; Brédif, M.; Pierrot- Desseilligny, M. An accuracy assessment of automated photogrammetric techniques for 3D modelling of complex interiors. Intelect. Arch. Photogramm. Remote. Sens. Spat. Inf. Sci. 2012, 39, 23-28. [CrossRef]

34. Klippel, F.S.; Prager, G.L.; Mezzomo, P.; Bolina, F.; Tutikian, B.F. Comparative study of fire resistance and acoustic performance of ceramic brick walls in concern to NBR 15575 in residential buildings in Brazil. DYNA (Medellin) 2018, 85, 53-58.

35. Fernandes, B.; Gil, A.M.; Bolina, F.L.; Tutikian, B.F. Thermal damage evaluation of full scale concrete columns exposed to high temperatures using scanning electron microscopy and X-ray diffraction. DYNA (Medellín) 2018, 85, 123-128. [CrossRef]

36. American Concrete Institute (ACI). TMS-The Masonry Society-ACI TMS 216.1-Code Requirements for Determining Fire Resistance of Concrete and Masonry Construction Assemblies; ACI: Farmington Hills, MI, USA, 2007.

(C) 2019 by the authors. Licensee MDPI, Basel, Switzerland. This article is an open access article distributed under the terms and conditions of the Creative Commons Attribution (CC BY) license (http://creativecommons.org/licenses/by/4.0/). 